\section{Intersections}

Canadian Journal of Music

Revue canadienne de musique
Intersections CANADIAN JOURAL OF MUSIC

\title{
Privileging Narratives: Singing, the Polish Tatras, and Canada
}

\section{Louise Wrazen}

Volume 27, numéro 2, 2007

URI : https://id.erudit.org/iderudit/1013113ar

DOI : https://doi.org/10.7202/1013113ar

Aller au sommaire du numéro

\section{Éditeur(s)}

Canadian University Music Society / Société de musique des universités canadiennes

ISSN

1911-0146 (imprimé)

1918-512X (numérique)

Découvrir la revue

Citer cet article

Wrazen, L. (2007). Privileging Narratives: Singing, the Polish Tatras, and Canada. Intersections, 27(2), 60-80. https://doi.org/10.7202/1013113ar

\section{Résumé de l'article}

Le chant traditionnel des Górale de la région montagneuse des Tatra en Podhale se caractérise par une simple phrase mélodique et deux lignes de texte. L'importance narrative de ce chant est présentée, de ses racines à la diaspora : collectivement, ces chants constituent un récit régional en Pologne qui offre le cadre d'expressions personnelles construites spontanément dans l'action et intégrées au discours social; au Canada, le récit individuel est subsumé au profit d'une narration collective qui situe un espace significatif entre ces deux mondes. En dernière analyse, la centralité de la musique dans l'expérience et l'expression délibérée de différence est renforcée au sein d'une réalité multiculturelle, transnationale et globalisée.
Copyright @ Canadian University Music Society / Société de musique des universités canadiennes, 2008
Ce document est protégé par la loi sur le droit d'auteur. L'utilisation des services d'Érudit (y compris la reproduction) est assujettie à sa politique d'utilisation que vous pouvez consulter en ligne.

https://apropos.erudit.org/fr/usagers/politique-dutilisation/ 


\title{
Privileging Narratives: Singing, the Polish Tatras,
} AND CANADA

\author{
Louise Wrazen
}

This paper traces the significance of singing through the transition of displacement from a European homeland to a dynamic diasporic reality in Canada. ${ }^{1}$ In so doing, it contributes to an ongoing concern with multicultural subjectivities and with the exploration of "mosaics" in the study of music in Canada, in particular. ${ }^{2}$ More specifically, this study focuses on the Gorale (Highlanders) from the Tatra-mountain southern region of Poland. ${ }^{3}$ When I first began my research with the Gorrale in Canada, the United States, and Poland in the 1980s, I was struck by the relative absence of extended narrative songs in their singing. ${ }^{4}$ Instead of hearing longer lyric songs or ballads (such as found in other areas of Poland and south-eastern Europe), I encountered tunes lasting less than a minute when performed. Indeed, I soon learned that the traditional singing style from this Podhale region of Poland is characterized by a preponderance of these brief melodies of one or two phrases of music and a single couplet of text. Already aware of a Górale propensity for effusively elaborating on stories, jokes, and tales, ${ }^{5}$ I was puzzled that this narrative predisposition did not find expression in other domains of expressive culture-that is, in a corresponding proclivity for extended strophic song forms. ${ }^{6}$ This paper arises out of this initial confusion, and proceeds to explore the quality of narrative as it relates to these Górale songs and singing. Specifically, I suggest that singing even these brief, epigrammatic songs compellingly tells stories.

1 Some of the ideas in this paper were first presented at the meeting of the Canadian Society for Traditional Music in 2005 in New Westminster, British Columbia, and at the annual meeting of the Society for Ethnomusicology in Hawaii in 2007. My thanks to Christy DiFelice for her help with the electronic form of the transcriptions. I also am grateful to Timothy Cooley and the anonymous reviewers for their comments.

2 Beverley Diamond has argued most consistently for this (see, for example, 1994, 2000, 2001).

3 I adopt the plural "Górale" as both noun and adjective, singular and plural, masculine and feminine, in an effort to avoid the complexities of declensions and also as a way to promote gender-neutral designations.

4 My research among the Gorrale in the greater Toronto area (GTA) of Canada began in 1979, with more intensive work from 1982 to 1986 ; I also have undertaken fieldwork in Chicago $(1983,1985,1986)$ and in Podhale $(1985,1989,2002,2004,2006)$. I am grateful to the support of the Social Sciences and Humanities Research Council of Canada for support at various phases of this work.

5 See, for example, some of these stories as presented by Kazimerz Przerwa-Tetmajer (1865-1940), an author of the "Young Poland" movement (Przerwa-Tatmajer 1957).

6 It would be inaccurate to suggest that there are no strophic songs in Podhale. The popularity and dominance of short texts, however, can be traced to as early as the mid-19th century through early collections (Cooley 2005, 92-94). 
This paper also explores how these narratives are closely tied to performance, and examines what happens when the telling of these narratives is relocated to North America. My primary frame of reference rests among the Gorale community in the greater Toronto area of Canada. My main objective, therefore, is to elaborate on the meaning and intentionality of diasporic music making as it unfolds within the interstices of homeland memories and new world constructions of identity and belonging. As such, this study is a part of an inquiry in ethnomusicology exploring music performance among subcultures in diaspora (Slobin 1993/2000). ${ }^{7}$ This paper addresses two main questions. First, what are the dominant narratives articulated through singing, and what is their relationship to the homeland? Second, how are these stories being told? In other words, what is the relationship between text, music, and the performative agency of this expression?

Before addressing these questions, I turn first to briefly consider what is generally understood by the word "narrative," and do so with the proviso articulated by Mark Slobin that "terms are creatures of discourse somewhere between stalking horses and red herrings" $(1993 / 2000,12)$ and, like James Clifford's "translation terms," may be used in "strategic and contingent" ways (Clifford as quoted in Slobin 1993/2000,12). Most fundamentally, a narrative implies a story, though the manner in which this is done varies. At the risk of appearing pedantic, I turn to two concise dictionaries to elaborate on this as a point of departure. Oxford, in defining narrative as "a spoken or written account of connected events," locates narrative firmly within the constructs of language. Narratives in music, therefore, similarly can relate a story through its associated texts, the most obvious examples being those associated with an expansive strophic form (such as ballads or epics). ${ }^{8}$ Additionally, insofar as music may be compared to a language, it can be argued that semantic meaning is found in the music (as sound) itself. This possibility has animated discussions in musicology in particular (see Nattiez 1990 for a summary and consideration).

Webster's dictionary, in defining narrative as "the art or practice of relating stories or accounts," omits any explicit reference to language-be it through speech or writing. In doing so, it invites us to consider the performative act itself as contributing to, or even creating, the narrative. Gender studies have elaborated on this perspective, notably with the introduction of the concept of performativity, which positions performance as central to the construction of meaning: acts "are performative in the sense that the essence or identity that they otherwise purport to express are fabrications [author's italics] manufactured and sustained through corporeal signs and other discursive means" (J. Butler 1990/2006, 184). This also has been explored in folklore studies through performance-centred approaches to oral narrative (see, for example,

7 It is beyond the scope of this paper to interrogate the concept of diaspora. For further discussion, see, for example, Clifford 1997, Safran 1999, Slobin 2003.

8 Examples are numerous, and notably include the epic ballads of areas of the former Yugoslavia (see Lord 1960/1976). More locally, the 2005 conference of the Canadian Society for Traditional music provided an opportunity to hear a number of ballads sung by Rosaleen Gregory and Rika Ruebsaat as part of the session "Magic and the Supernatural in Traditional Balladry." 
Bauman (1986), Braid (1990), G. Butler (1992)), where, insofar as an audience may be involved in this process, narrative becomes discourse (G. Butler 1992). Narrative and discourse become interrelated here. ${ }^{9}$ The active, often interactive, quality of narrative as performed (though not as necessarily tied to text to convey meaning or a story) also informs music, and has been explored variously in music research. ${ }^{10}$ This paper rests on the assumption that the act of telling, or the manner and style of performance, can therefore convey a narrative-be it associated with text or not.

The distinction between these two definitions becomes particularly relevant when considering the construction of narrative through music in a transgenerational, transnational context among the Gorrale. This paper is founded on the understanding that Gorale short epigrammatic songs collectively constitute a coherent regional narrative. Notably, however, this narrative is foregrounded variously and articulated differently depending on the time and place of performance. Whereas in homeland Podhale this regionally compelling narrative provided a backdrop upon which individual stories also could emerge through spontaneous performance dynamics that included dance and carefully selected texts, in diaspora any individual story is subsumed in favour of a dominant collective narrative that now contributes towards locating a meaningful space between the two worlds of homeland and new home. This change is consistent with the "working through, or working out" (suggested by Homi K. Bhabha), which "makes it possible for us to confront that difficult borderline, the interstitial experience, between what we take to be the image of the past and what is in fact involved in the passing of time and the passage of meaning" $(1998,36)$.

This "space of enunciation" (Bhabha 1998) provides an opportunity for what Slobin has identified as a process of "reevaluation" where a subculture's musical energy goes into working over its own music to best represent the "us" to outsiders $(2000,95)$-and, I would suggest, to insiders as well. In this way, the "representation of cultural distinctiveness, whether through images, sounds, movement, or words" may be a powerful means of both legitimation and control (Diamond 1994, 11). Although this form of cultural representation is often

9 A distinction between these two terms is considered by Cooley, who views narratives as "histories, the presentation of selected facts and myths to support one's ideas about oneself or another," whereas discourses are "the interpretations of that historical narrative, the efforts to give meaning to the narrative" $(2005,62)$. Insofar as the selection of facts and the creation of myths may already be a part of the interpretive process involved in giving meaning, this is not a distinction in which this discussion deliberately engages. See, also, Sugarman's consideration of discourse, after Foucault (Sugarman 1997, 28-30).

10 The supporting literature here is too numerous to cite. For an early theoretical formulation, see Feld (1984). More recently, Timothy Rice (2001) has provided a valuable overview. Whereas the exploration of musical meaning has animated ethnomusicology, an explicit consideration of narrative has been rare. A search of the major journals in the field reveals only seven articles with the word in their titles (since 1980). Most use it as synonymous with story and give no explicit consideration of the term (Zhang (1992), Weintraub (1994), Tokita (1996), Booth (2000)). Others approach it with more deliberation (Stock (1996)), especially in popular music studies (Fairley (1989), Dimitriadis (1996)). Insofar as Fairley argues that "musical meaning is negotiated between elements of performance and between performers and audience" (although only tacitly linking this to narrative), his understanding is more nuanced (and consistent with my own) (Fairley 1989, 1); Dimitriadis provides a deliberate distinction between "closed narrative" and its absence that is relevant to my discussion. 
characterized as heritage (Kirshenblatt-Gimblett 1995), I here choose to dwell less on this relatively static conceptualization in favour of the more dynamically charged potentialities of performances that articulate deliberate choices of association and affiliation.

The primary purpose of the following discussion, therefore, is to elaborate on this interstitial experience of association, in particular by exploring the concept of narrative as it informs this process. It argues that the quality of narrative is a fundamental component of music performance; performance and narrative provide a compelling means to map present diasporic experiences onto a larger framework of homeland memories. This paper will proceed by first introducing the Gorale and their songs with reference to their construction of narrative in the homeland. It will then consider representations through performance in Canada.

\section{Górale AND Singing In Poland}

Although the word Gorale (Highlanders) can refer generically to any group of people from the hills or mountains (góry), those in this study come from Podhale, located on the northern side of the Tatra Mountains of the Carpathian mountain range that defines Poland's southern border with Slovakia. Most of the Górale with whom I spoke in the 1980s arrived in Canada in the 1960s and 1970 s, ${ }^{11}$ and this may be regarded as the first generation of deliberately defined "Górale" activity in Canada. ${ }^{12}$ This early generation of Górale, mostly from the northern villages of Podhale, brought vivid memories of spontaneous singing and dancing with them to Canada. These memories, together with further ethnographic research in Podhale, contribute to the following contextualizing discussion of singing in Podhale.

Distinguished from other parts of Poland by their local dialect, and their material and expressive culture, these Gorrale have perpetuated a strong sense of regional individualism that has contributed to making them a distinctive group within Poland ${ }^{13}$ as well as in Canada. ${ }^{14}$ In particular, Górale maintain a strong local allegiance to a homeland defined foremost by the mountains (Wrazen

11 See Wnuk (1985) for a history, and also Znaniecki and Thomas (1996) for an abridged version of the classic early twentieth-century study of Polish emigration to North America. Although appearing to be geographically isolated, Gorale have had a long history of association with the outside world through tourism, ethnographic inquiry, and the seasonal or permanent departure from home in search of work, leading many to other areas of Europe and eventually to North America in the 1870s and 1880s (see also Cooley (2005)).

12 After government restriction of movement in the 1980s that culminated with the imposition of martial law in 1981, emigration increased following the fall of communism and the first democratic elections in Poland in 1989. Movement and possibilities of communication have continued exponentially since that time.

13 For further discussion, and for a consideration of some of the relationships between the regional and national and international, see Wrazen (1988) and (Forthcoming), Pine (1996), Manouelian (2000), Ćwiżewicz (2001), Cooley (2005).

14 Concern for maintaining a distinct identity in Canada led the Gorale to distinguish themselves from the larger Polish immigrant community by forming an independent fraternal organization in the 1980s (The Polish Highlanders Association of Canada/Zwiazek Podhalan w Kanadzie), modeled after the much older Polish Highlanders Alliance of America (Zwiazek Podhalan w Ameryce), based in Chicago. 
2007). On the one hand, this landscape of uncompromising topography and harsh climate has been responsible for a history of physical hardship and economic struggle; on the other hand, it has nurtured a tradition of transhumant pastoralism that has been valorized in expressive culture (and rendered virtually obsolete by the post-war communist regime). In addition, years of poverty and feudal exploitation, together with the political reality of the partition of Poland in 1792 and subsequent lengthy Austro-Hungarian rule (until 1918), have cultivated social and musical relationships across these slopes to the south while also provoking feelings of regional independence. These have all combined to contribute to the formation of a local mythology built around themes of heroism, stamina, and defiant individualism framed within this landscape and frequently referenced in songs and other cultural expressions.

Some of these stories are most explicitly presented in a number of longer songs that form part of the Gorale repertoire together with the short tunes to be discussed shortly. One such well-known strophic song, for example, is named after a famous peak ("Krywan'); numerous others relate the story of Janosik-a legendary Robin Hood-like figure from the Slovakian side of the Tatras who lived from 1688-1713. His story of bravery and betrayal has captured the imagination of the Polish Gorale in a common spirit of trans-Carpathian hardship and heroism. These longer songs are distinct in several ways. First, they are strophic with a closed narrative form; that is, their story lines are set and complete, rather than remaining open-ended and malleable in performance. ${ }^{15} \mathrm{Also}$, relationships between texts and tunes are relatively fixed. Second, at least some of these songs are attributed to a known composer (see Motyka 2004, 172-261; Cooley 2005, 29-31). Finally, many of these are known to originate from the other side of the Tatras. In this way, they are recognized (at least by many musicians with whom I have spoken) as not being from Podhale, but rather as having been adopted by Górale into their repertoire. As such, Górale taxonomies inevitably distinguish them from the other segment of their repertoire-those shorter songs ${ }^{16}$ that are regarded as unequivocally from Podhale and to which I now turn (Stęszewski 1980, 32; Wrazen 1988, 77-81; Ćwiżewicz 1995; Cooley 2005, 53-57).

These brief polyphonic songs from Podhale comprise two lines of text, each containing twelve to fourteen syllables with a caesura in the middle and with the second line often repeated in performance. The music consists of either a single melodic phrase repeated or two phrases (with the second possibly repeated). When sung non-metrically and a cappella, these are known as "pasterskie" (pastoral) or "wierchowe" (roughly translated, this word references mountain peaks). Typically, one person begins to sing and then others join in on the lower part(s). A loud, resonant vocal quality (with men and women singing in the same regis-

15 As pointed out by Dimitriadis in his discussion of hip hop, music relying on a closed narrative offers less opportunity for spontaneity in performance than that with an absence of strict narrative (1996, 181). His discussion provides an interesting parallel with styles of singing in Podhale as discussed here.

16 The word "song" is somewhat problematic, especially as applied to the short, non-strophic repertoire, in particular since Gorale prefer the words "spiew" (singing) or "nuta" (note) and tend to avoid the word "piosenka" (song) (also Wrazen 1988, 75; Cooley 2005, 23). 
ter) and free-rhythmic performance style, often with long pauses between the three phrases, make these songs ideal for singing outdoors among the fields and valleys (a performance milieu I have both experienced and been told about by Górale who shared their experiences with $\mathrm{me}$ ). At least at one time, this singing formed an indispensable part of any gathering. Friendship, camaraderie, and the affinities felt in the intensity of notable social occasions may be embodied in the very act of spontaneously singing together. As I have witnessed them, these singing gestures often punctuate another sphere of social interaction already under way (such as talking, eating and drinking, dancing) and provide a form of interjection, or musical exclamation, with their intensity and brevity.

In 2006, this occurred in the village Witów, in Podhale, during the celebration of the town's $400^{\text {th }}$ anniversary. Following the lengthy outdoor mass held outside the tiny church in the July heat, everyone reconvened in the old wooden L-shaped town hall for a meal. There were over one hundred of us seated along long wooden tables covered in white tablecloths and laden with platters of hot food. After the numerous speeches had finished and the meal was eaten, some left in search of fresh air outside while others lingered over dessert inside. Suddenly a woman's voice pierced the general din of sound to begin a song from one corner of the hall. Others sitting around her (all middle aged, and mostly men) joined in at the appropriate time. They all knew the well-known tune, ${ }^{17}$ and quickly oriented themselves to the text that she was singing.

Young girl from Witów-
a beautiful setting;
through the centre of Witów
rushing waters flow.
Witówna $z$ Witowa-
piykne połozenie;
przez środek Witowa
bystra woda plynie. ${ }^{18}$

The performance was not rushed, and there were long pauses between each of the three phrases of tune (the second line of text was sung twice)-as though the sound was being given time to waft out of the open windows into the meadows outside. With each repetition of the music, the singing seemed to increase in intensity. Though there were no more than five singing, the cumulative effect of the men and women singing in the same high register in such strong chest voices was notable. Yet no one seemed to heed the singing; it was simply a part of the general gathering. As the only spontaneous singing during this part of the event, it both punctuated the afternoon and provided a compelling homage to the town-at least as effective as any of the previous proceedings.

A number of characteristics of traditional Gorale singing are illustrated here. First, the performance style depends on a single individual (often a woman) beginning with the top line and others joining in on the part below, which usually follows primarily in thirds, with occasional fifths. The vocal quality is a strong chest tone, and women and men sing in the same register-sometimes resulting in some degree of strain in the men's voices. Second, the relationship between

17 Metric versions of this tune are found in Karpiel Bułecka 2000, 3; Motyka 2004, 179; Cooley 2005, 14. See also note 34 .

18 All translations are my own and tend towards a literal translation, thereby hardly doing justice to the poetic quality of these evocative texts. 
tune and text is extremely flexible. In the above performance, the tune chosen was well-known and often linked with another popular text extolling Gorale music (see song text associated with note 34). Third, the choice of the text is left to the person leading, and often is improvised to reference the local and immediate (such as here, where the text contributed to the musical homage to the town of Witów).

The following example provides another illustration of this characteristic song type, this time as found on a commercially produced compact disc. Containing forty-three tracks averaging about one minute in length, the recording provides a commercially encoded testament to the brevity of Gorale tunes. In Example 1 a single melodic idea is repeated three times to the $a b b$ text. In addition to illustrating the polyphonic singing led by a strong (female) voice on the upper part and men and women singing in the same octave, it also shows some intervallic flexibility between the two parts (thirds and fifths), including an unexpected sixth resulting from the variation extemporized by the lead singer in the third repetition. ${ }^{19}$

Hey there was a lovely young girl, one hundred sheep were grazing; hey a young boy came to hera small light went out.
Hej śwarne dziywce było, sto owiecek pasto; hej psysed ku niej siuhajświatełko zgasło. ${ }^{20}$
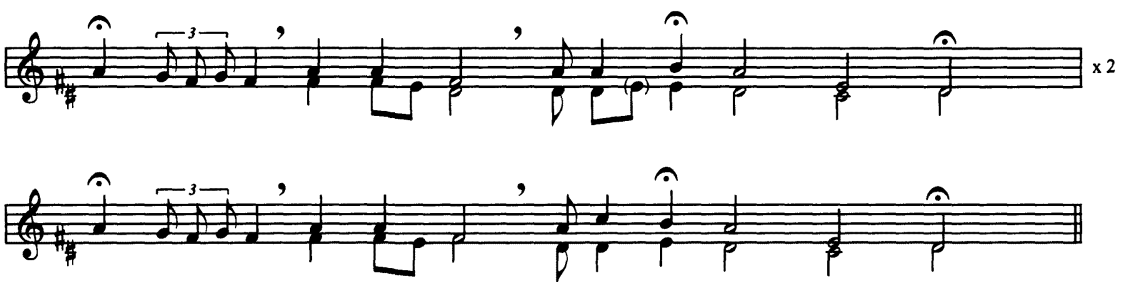

Example 1. A pasterska song from Podhale.

The texts to these tunes are generally drawn from a large and widely known common repertoire. Yet although it is possible to sing one of the many wellknown, pre-existent texts (Sadownik (1957/1971) contains 1250 different texts as well as 137 tunes), pride is taken in the ability to extemporize new words (as in the singing from Witów), just as it is possible to musically elaborate the melody (or tune) with subsequent repetitions (as heard in the third repetition in Example 1). ${ }^{21}$ Through their texts, both of these songs clearly contextualize the

19 Discrepant timbres and tunings in the lower parts lead to an overall sound rich in "participatory discrepancies" (to borrow a phrase from Keil (1994)) and far removed from the organum that the second half of the transcription alone might suggest. In addition, many of the notes are approached with a broad scoop from below, in particular by the men.

20 As heard on Regle: Hej Poronin, Poronin. 2002. Zakopane: Harnaś-audio (Harnas CD-001).

21 I recognize that introducing the concept of the tune, with its implied fixity, may appear problematic here. I wish to imply, instead, a foundational sense of a tune as a point of departure for vocal elaboration. Rather than singing the same phrase three times, many experienced singers will vary the second, 
performers in a sense of the local, be it social (village), geographical (river), or socio-economic (pastoral). The following discussion turns to these texts.

Although Sadownik (1957/1971) provides an invaluable reference to texts organized thematically, 22 for this discussion I have chosen song texts either from my own experiences or from those of Gorale (both in Canada and in Poland) who have shared their experiences of the past in Podhale with me. In so doing, I use memory as shared in recollections as an explicit research tool in order to gain an insight into a sometimes elusive, undocumented past (see also Rice 1994) - a methodology distinguished from one that uses memory as an interpretive filter through which to consider nostalgia. I here include, in particular, many texts provided by Franek Mrowca, an experienced fiddler who, before moving to Canada in the mid-1980s, was active in playing at numerous villages in Podhale. During the course of our many hours of conversation and playing, he was not only able to recall specific song texts, but also to discuss the circumstances under which they were sung. In this way I gained an insight into the dynamics of singing, music, and dancing in village life in a Podhale long past. In short, I gained access to data from Podhale, if not explicitly collected in Poland, that in turn informs the following discussion (see also Wrazen 2004).

Many song texts draw on some retrospective of the landscape to contextualize a reflection of a more personal nature. In so doing, these songs contribute to a general understanding of the Górale as locally situated within a specific landscape and worldview while also potentially giving voice to more personal sensibilities. The second text quoted above, for example, accesses both the general and the personal by combining two prominent themes frequently developed in these songs: pastoralism indebted to the mountain landscape, and personal experience related to male/female relations in particular. Texts also can present a more explicit first-person narrative contextualized within a shared natural world, as found in the following two texts. The first provides an opportunity for a woman to complain about her philandering husband:

$\begin{array}{ll}\text { What use to me is this greenery, } & \text { Co mi z tego zielo, } \\ \text { when it has a dry flower; } & \text { kie na nim suchy kwiat; } \\ \text { what use to me is this man } & \text { cos mi z tego chlopca } \\ \text { who loves the entire world? } & \text { kie kuocha caly świat. }{ }^{23}\end{array}$

In the second, the song offers a way for the singer to express individual despair, and even contemplate suicide (I was told that this was the result of a pregnancy

and, in particular, the third repetition. As I have already shown (Wrazen 1991) some of this variation is lost as tunes become more schematized into a canonic, fixed repertoire (in particular on the stage, and in diaspora settings). Furthermore, I am writing explicitly of singing as performed by non-instrumentalists (instrumentalists may well conceive of the repertoire in different terms). In general, this performance style exhibits a spontaneity in performance that characterizes an absence of strict narrative (Dimitriadis 1996, 181).

22 A large selection of texts taken from recordings made in the U.S. in the late 1920 s is translated in Cooley and Spottswood (1997a and 1997b).

23 I am grateful to the late Mr. Franek Mrowca, as well as to his wife, Kasia, who shared in his reminiscences. Unless otherwise stated, the song texts are drawn from his memories of specific occasions. 
outside of marriage in this particular case). Again, an initial reference to the landscape (here a well-known local river) contextualizes the more personal:

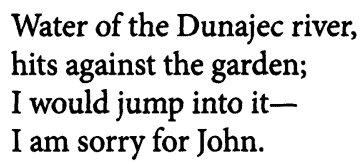

Water of the Dunajec river, hits against the garden; I would jump into itI am sorry for John.
Dunajecko woda, bije do uogroda; skocylabyk do nie- mnie Janicka skoda.

Through such juxtapositions, these songs can express a powerful synoptic thought that reveals an intensity and honesty otherwise often left unspoken. Some Górale have suggested to me that it was possible to express through song what would have been difficult or impossible to express through speech (and as arguably illustrated in the two above examples). As a result, the words sung were often deliberately chosen and often not inconsequential. Indeed, many Górale have an uncanny ability to remember texts that impressed them and recall them within the context of the original performance setting. For example, more than one woman is able to recall some of the specific texts sung to her at her wedding even many years later-much in the way that other brides can remember details of flower arrangements or dress. The actual substitution of song for speech was memorably demonstrated to me in one particularly awkward domestic situation where a woman was no longer speaking to her estranged husband even through they shared living quarters. Working in the kitchen, in a moment tinged with bitterness and (and possibly) regret, she chose to sing a biting text obviously directed at him when she knew he was passing by in the hallway and within easy earshot. On another occasion, a young woman sang the following words for me:

\author{
Rush water, rush water, \\ rush waters water; \\ why did we ever \\ fall in love so young.
}

\author{
Sium wodo sium wodo \\ sium wodzicko wodo; \\ pocoś sie nom było, \\ tak zakuochać mlodo. ${ }^{24}$
}

Given that she was twenty-three and pregnant with her third child at the time, this well-known text may well have had more than coincidental relevance to her.

These shorts songs also can be performed metrically, where they constitute an indispensable part of a man's prerogative in a dance for a single couple, a dance generally known as "the gorralski." Briefly outlined, in this dance a man approaches the musicians, sings a tune and text, then turns and waits for his partner to arrive on the dance floor while the musicians begin to play the tune. His partner is brought to the floor by a friend (following prescribed dance movements), who then leaves. The woman then begins to dance with her partner. The couple dances, without physical contact, for as long as the man chooses. When he has had enough, he stops, abruptly leaves the floor and returns to the musicians to sing another tune. The woman returns to the side to wait until she is again brought to the floor, where they dance again. This sequence can continue, in principle, for as long as the man wishes, though in practice a single set usually 
comprises from three to five separate tunes. After concluding by swinging his partner in a circular motion, the man concludes his set, and another man is then free to approach the musicians for his dance.

This dance was arguably the most important social context for male singing, and the choice of text was at one time carefully noted for possibly revealing an insight into the dancer's personal feelings, in particular towards his partner. This could subsequently lead to a response, either on or off the dance floor. Performance (singing and dancing) here contributed to a cultural construction of reality, where (as suggested by Edward Schieffelin) participants were "engaged with the symbols in the interactional creation of a performance reality, rather than merely being informed by them as knowers" $(1985,707)$. Songs here could reveal a quick wit, skilful poet, and deliver a message of consequence, where, together with dancing, they contributed to a constructed and emergent social reality (Schieffelin 1985, 721). Jealousies, love, rivalry, and revenge all could find their expression through such performance, these articulated differently depending on the age, status and gender of the performer. ${ }^{25}$ As recounted to me by fiddler Franek Mrowca, who played for many dances, even the following seemingly innocuous song text could have significant implications when sung in a pointed and deliberate manner in reference to a specific girl:

I don't have any fields,
only one neat ridge;
but I do have instead,
a lovely little sweetheart.
Nimom pola nimon
ino skibe sktadniom;
ale se mom za to,
kuochanecke tadnom. $^{26}$

In this way, singing could provide a vehicle for public expression, or even announcement. As one woman recalled, it was not until her husband, who was then just another boy, sang the following text in front of the entire village before dancing with her that she knew that he was serious and had good intentions (personal communication, 13 February 1986):
Zgrabneśs dziywce zgrabe, drobne kuości $w$ tobie; nie zol cie uoblapic, tak przytulić ku sobie.

Women were silent within the context of the dance and therefore could not respond to positive messages, nor could they retaliate from an unpleasant text. A woman might initiate a non-metric song from the side of the dance floor, however. This could provide her, too, with an opportunity to comment and participate in the discourse. ${ }^{27}$ The following text could serve this purpose, for ex-

25 I have considered this dancing as gendered performance and as socially situated in greater detail elsewhere (Wrazen 2004).

26 Though the obliqueness of this reference may seem innocent to our sensibilities today, the potential gravity of this text is better understand within the context of a dialect and proclivity that does not emphasize the verb "to love," but which favours expressions such as "rada cie widze" or "rada cie mom" (literally: joy I see in you, or joy I have in you).

27 A re-creation of this can be heard on the $8^{\text {th }}$ band of a 1995 recording, where some women's singing begins while the music is still playing for a goralski dance sequence (Music of the Tatra Moun- 
ample. Using the metaphor of a blooming flower, it takes up the cause of a girl's love for a young man.

Give me mother give me, where they ask for me; when a lily is blooming, then is the time to pick it.
Daj mnie mamo daj mnie

kielu gdzie pytajom;

kiele lilja kwitnie, wtedy jom tak dajom. ${ }^{28}$

As already suggested, thematically many of these song texts include a contextualizing, general visual image that positions the singer (and any subsequent personal messages) within a socially shared common local reference, often involving the landscape. When, for example, someone sang a text such as the following, they could convey any potentially personal revelations onto a general scaffold of shared Gorale worldview informed by the landscape of the Tatras with its implicit history of pastoralism and tales of hardship and survival.
Falling they are falling,
all the hills upon me;
I am not afraid of them, rather will I crouch behind them.
Walom ci sie walom, syćkie góry na mnie; zachylym sie za nie. jo sie ik nie boje,

Listeners here have a choice as to whether to acknowledge any intended personal component of the message, or merely to respond to the overall, shared message of hardship and survival. In this way song and singing could articulate stories at two narrative levels. At one level, when considered together as a coherent repertoire, these songs, though individually brief, together comprise a background framing narrative of a locally generated Gorale collective identity rooted in the regional landscape and community. On another level, when considered individually and linked to specific performances and people, singing also enabled individuals to express their personal stories in a socially sanctioned manner and allowed them to participate in a public discourse.

\section{Górale Songs in Canada}

Occasions and opportunities for singing obviously changed for Górale in Canada. Although during the 1980s Gorrale often sought an opportunity to sing and dance as they may have done in Podhale, as the community settled, aged, and grew, spontaneous performances gave way to an increasing emphasis on the ensemble as the main music-culture bearer of the community and on the stage as the primary performance space. In contrast to the early years of this community, when there was one formal ensemble to rehearse and perform Gorale music and dance, today there are several. These are focused on training a younger group of dancers, singers and musicians, most born in Canada or arriving here at a young age. This is in contrast to the 1980 s, when many of those taking part in performances had grown up in Podhale and learned to sing and dance there-either informally or in a regional ensemble.

28 As sung in Podhale, June 1985. 
The following observations stem from this most recent period in Górale performance in Canada, when most songs are explicitly taught to those participating with a view to choreographed performances. In these settings, texts and tunes become part of a finite canonic repertoire deliberately taught and learned for staged performances. ${ }^{29}$ Building on the contextualizing discussion of Górale singing in Podhale in the previous section, I now turn to map the transpositions of diasporic experience onto these song genres to reassess the role of narrative in ongoing performance away from homeland. ${ }^{30}$ To this end, this discussion focuses on one particular occasion as an example of current normative practice in Canada. While acknowledging the potential risks of appearing to essentialize diasporic performance, I nonetheless refer to a specific ethnographically based example as a point of departure and concrete illustration of ongoing practices to reinforce the immediacy of these music performances.

During the time of this research, one ensemble (subdivided into two groups and ranging in age from about five to sixteen) would rehearse weekly in the hall of the Polish Highlanders' Alliance of Canada, often in anticipation of a specific upcoming event. Their performances generally include several opportunities for singing: some unaccompanied non-metric tunes (pasterskie), singing for dancing, and a strophic song that may accompany entrances or exits. Notably, the texts chosen for the non-metric songs typically extol the beauty of the landscape and refer to the distinctive qualities of Górale music and life.

In the fall of 2005, a Górale community-based dance provided an opportunity for these two groups, collectively known as Harnasie, ${ }^{31}$ to perform. Following the banquet meal (and preceding the general dancing to music played by a five-piece band brought from Podhale for the occasion), the members of the ensemble performed for their parents and others in the audience of about two hundred. Their entire program lasted about twenty minutes and featured the two age groups separately, with the younger group of eighteen children performing first, followed by twenty-three in the older group. Each program included a choreographed entrance and exit, one or two sets of the góralski dance sequence, and some singing; in addition, the boys from the older group performed a set of the brigands dance (zbójnicki). The younger group framed their performance with two verses of a historically-influenced text sung to the wellknown march known to some simply as "Madziar" (the Hungarian). ${ }^{32}$

29 This repertoire is determined by those teaching, who inevitably teach from their favourite tunes and texts. Learned explicitly, and heard in a limited number of settings, this repertoire now has fewer opportunities for expansion-both in terms of number of melodies and approaches to variation and elaboration.

30 The word "transpositions" also has been used by Gay Breyley, who writes of "complex transpositions" to conceptualize diasporic cultural and musical practices in terms of cultural hybridity and hyphenation in her study of indigenous and Jewish performances of mourning in $20^{\text {th }}$-century Australia $(2007,97)$.

31 This is roughly translated as brigands or robbers, who were associated in particular with the period of Janosik.

32 According to Zakopane musician Jan Karpiel Bułecka, this tune, which is generally played for welcomes, arrivals and farewells, is also of Hungarian origin (pers. comm., June 1985). See also Cooley 2005, 33. For transcription see Mierczyński (1930/1973) no. 94, reprinted in Cooley 2005, 38. 
Hey there from the Tatras,

from under the grey Tatras

hey the warm southern wind blows;

hey it blows, blows with the news

that men are coming

from the valleys.

At the very front

Galica is riding,

four thousand troops he's bringing;

four thousand Gorale alone,
Hej tam z pod Tater,

$z$ pod siwyk Tater

hej poduchuje holny wiater;

hej poduchuje, leci nowinom

ze chłopcy idom ku dolinom.

Na samym przedzie

Galica jedzie,

styry tysionce wojska wiezie;

styry tysionce samyk góroli,

hey with their hatchets for the Russians. hej cuipagami na moskoli.

Rather than singing the text often associated with this tune (from which the tune derives its longer name: "Hej Madziar pije" ["Hey the Hungarian is drinking"]), the group sang a more didactic text referring to a well-known $19^{\text {th }}$ century uprising in the village of Chochołów.

The older group also included some non-metric songs. After an initial dance formation, the group sang the following, led by one young woman with a strong voice:

Singing and playing

these are pleasures of the world;

if only they'd play for us

the years would dissolve.
Spiewanie i granie, to uciecha świata;

kieby nom zagrali

przestyby nom lata.
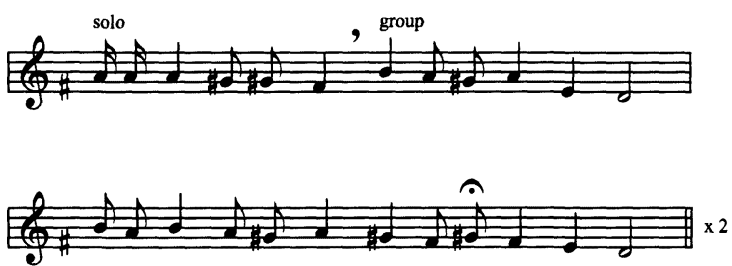

Example 2. A pasterska as sung in Toronto.

The lower part was not audible in performance; instead, most members of the group sang with the lead singer, who was amplified. ${ }^{33}$ In my observations of such ensembles in Canada, I have noticed that most of the younger members have a relatively difficult time learning and sustaining the lower part, and the older boys (in particular) have difficulties managing to sing with any authority, possibly out of a sense of inhibition when required to sing loudly and in the same register as the girls. During performances, both may benefit from the support of some strong singing from their instructors from the sides. As notably evident in this example, most tend to gravitate towards the top melody rather than the supporting lower voice within this polyphonic style of singing. The second tune the older group performed is particularly very well-known, and

33 The young woman begins the tune somewhat freely; it then settles into a metric regularity when the others join in. This tune is characterized by the Lydian sharp fourth degree that characterizes many tunes from Podhale. 
when combined with the text sung here it constitutes what Cooley has suggested can be considered the "Podhalan national anthem" (this tune was sung to a different text in Witów, as discussed earlier) (Cooley 2005, 144).

\author{
Górale Górale \\ music of the Gorrale; \\ the entire world I will roam \\ there's none like it anywhere.
}

\begin{abstract}
Górole górole
górolsko muzyka;

caly świat obejde

nima takiej nika. ${ }^{34}$
\end{abstract}

In addition, there were some sequences of dancing that, for the most part, relied on well-known texts and tunes. For example, one young man (greatly assisted by the singing of the musicians ${ }^{35}$ ) sang the following popular text to a well-known tune (see Example 3) to begin his set:
Hey I am going dancing
Hej jo se idem toncyć
you musicians play on;
hey and you, my friends,
can bring out a girl for me.
wy muzycy grojcie;
hej a wy mi, koledzy,
dziwcynke zwyrtojcie.
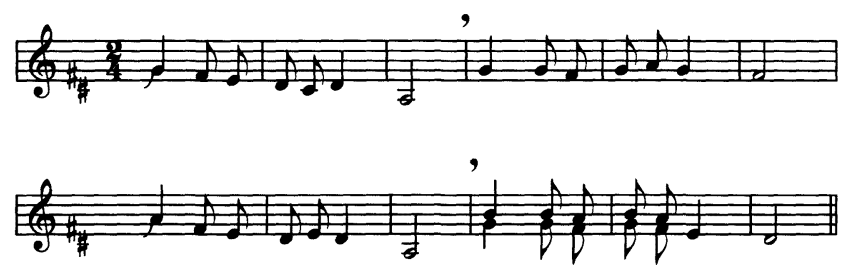

Example 3. The tune chosen to begin a dance sequence in Toronto.

In another góralski sequence, a little boy (about five years old) charmed the audience not only with his dancing, but also with his singing when he chose to address the musicians with the following text to request his dance:

Little I am little
I don't need much;
two meters of sausage
four kilos of bread.

Such moments clearly highlight the entertainment value of these occasions. They also reinforce the comfort of knowing that even the youngest members of the community are learning the traditions of their forebears.

34 See Cooley $(2005,144)$ for a reproduction of the melody (in strict meter), together with a variant text, as published in a booklet associated with the 1994 Zakopane International Festival of Mountain Folklore. This is the first tune appearing in the section devoted to the music of the Gorale from Podhale in Motyka 2004, 179. It also opens a publication by Karpiel Bułecka 2000, 3. See also note 17.

35 In the second line, the basy player helped the singer/dancer by singing above him (thereby adding the upper line in measure 10 and making the lower part virtually inaudible). This illustrates some of the fluidity in the concept of a tune, in particular as realized among instrumentalists (see note 18). A three-fold repetition of the tune is avoided for dancing; rather, each line of text is sung only once. 
Performances such as these now offer the most prominent opportunity for Gorrale singing in Canada. These aim to capture some essence of a Górale life and worldview through attention to traditional costumes, music of the string ensemble, dance, and singing-in which the text is explicitly evocative of the landscape, lifeways, and history of the homeland. Not surprisingly, the expression of a personal story has no forum within this narrative of collective identity. In an interesting reformulation, another performance by this ensemble included a duet constructed by juxtaposing two singers (boy and girl) and their texts within a kind of dialogue, operetta style.

Girl:

Hey why didn't you come when I was waiting for you, hey when the cold dew was settling upon me.

Hej cemu ześ nie przysel, kiek na cie cekała, hej kiedy zimno rosa, po mnie tosiodala.

Boy:

I went by the hilltop, you went by field and valley that's why I, passed you by girl,

Together:

Why aren't we both of the same mind, so that we could both meet on the hilltop.

Jo se posed wiyrskiym, tyś posta dolinom, temu jo sie $z$ tobom, moje dziywce minon.

Cemu my se toba, nie som jednyj myśli, coby my sie razym, we wiyrsycku zesli.

In this manner, the ongoing relevance of the vicissitudes of love and relationships are acknowledged within a highly controlled and rehearsed style of performance. This provides another example of the way in which performance manner and style are key to interpreting narrative. The landscape here referenced so evocatively no longer supports the expression of individual experiences and feelings as it did in Podhale, where song was a part of lived social experience. Instead, in songs such as these sung in Canada, the personal is overridden by a broader concern for the representation and affirmation of a collective Gorale individuality to be explicitly distinguished from a larger multicultural, urban mosaic.

The significance of this new narrative is not only that it is referential to a collective Gorrale ethos beholden to the homeland, but also that it is relative and locational in relation to mainstream (Canadian) culture. This is consistent with Bhabha's discussion of the construction of cultural authority within conditions of opposition; he suggests that groups "deploy partial culture from which they emerge to construct visions of community, and versions of historic memory, that give narrative form to the minority positions they occupy" (1998, 34). The narrative discussed here, therefore, assumes yet another dimension as those stories performed through song now articulate an ideology founded on a landscape, pastoralism, and heroism derived from memories far removed from current urban reality. Singing contributes notably to a narrative of identity 
and deliberate association. Stuart Hall's proposal (when discussing Caribbean and Black British cinemas) to "theorise identity as constituted, not outside but within representation" $(1990 / 1996,120)$ is germane to this situation as well. Hall argues that we should think of identity "as a 'production', which is never complete, always in process, and always constituted within, not outside, representation" (110), where the past "is always constructed through memory, fantasy, narrative and myth" (113). Within this dynamic paradigm, cultural identity, therefore, is:

Not an essence but a positioning [author's italics]. Hence there is always a politics of identity, a politics of position ... (113)

Among Gorale performance in Canada as explored here, the very act of singing is implicated in just such a politics of identity and position. This new narrative may now be in almost defiant counterpoint (or even opposition) to other potentially converging and emergent constructions of position within a complex Canadian multicultural reality. Here, the process of the telling forms the narrative at least as much as what is being told.

\section{Conclusions}

This paper has elaborated on the nature and quality of narrative in Górale songs and shown how they impart a variety of narratives despite the brevity of their form and regardless of the location of their performance. Its scope has extended diachronically from homeland experiences of the past to current performance practices in Canada. In thus intersecting a discussion of narrative with a diasporic experience and its homeland roots, this essay has provided an example of ongoing engagement with traditional expressive forms within new world subcultures. It also has promoted the relevance of ongoing attention to homeland experiences (often from the past) in the search for a richer understanding of current transnational practices.

Although the performative act of singing also can demonstrate a competence with heritage among younger generations (Kirshenblatt-Gimblett 1995), I have focused less on this than on exploring the ways in which singing contributes to a narrative of belonging when disassociated from the immediacy of homeland and attenuated within diasporic experience. Songs evocative of a regional landscape and traditional lifeways perpetuate references that are otherwise becoming increasingly vestigial, while an ongoing commitment to their performance inscribes them as informing a larger complex of emerging associations and identities. As suggested by Schieffelin, it becomes possible for performers and audience together to "co-create a new reality that recontexualizes particular problematical social circumstances" here, endemic to relocation, "and enables action to be taken in regard to them" $(1985,707)$. The performative act of singing articulates a narrative of association that privileges what otherwise may be becoming increasingly tangential, or even negligible. As patterns of identity become inscribed through singing, telling the story now becomes embodied as much in performance as embedded in song. 
In addition to elaborating on the significance of narrative in Gorale singing in particular, this study also reinforces the more general need for ongoing research on the dynamics and performance of expressive forms within a Canada increasingly defined by its multicultural, diasporic and transnational networks. Michael Adams has recently argued for the success of Canadian multiculturalism based on a history of experience, a long-established reality of pluralism (comprising a national minority group, an Aboriginal population, and a substantial immigrant population), and a poll suggesting that " 75 per cent of Canadians believe that overall, immigrants gave a positive influence on the country" (Adams 2007, 13). It remains essential, however, to nuance this understanding through ongoing research within specific, individual settings. As immigrants in a continuing engagement within a matrix of other communities in transition, and situated in a majority discourse, the example of the Gorale explored in this paper contributes ultimately to the larger discussion of what Beverley Diamond has more soberly identified as "fields of tensions." Diamond recommends that:

A close look at the fields of tensions inherent in the multiple perspectives at any social location may be one useful tactic in moving beyond a discourse that neutralizes the "rich tapestry" of cultures in Canada to one that enables a better understanding of the role that music does and can play in the power-laden, lived experience of difference. $(2000,75)$

Similarly, Tina Ramnarine has recently suggested moving away from a "purely celebratory approach to multiculturalism or to hybridity that continues to understand cultures as essentially discrete, defining their borders and attaching equal value to them" $(2007,7)$. Rather than focusing on a conceptualization of diasporic identities in terms of hyphenated realities that reduce complex experiences to the binaries of ethnicity and nationalism, Ramnarine promotes considering musical life in a multicultural society as part of political readings of social relations and creative processes (7). This also reflects a recent concern with a reconceptualization of our understanding of "mosaics" and "multiculturalisms" in terms of more fluid, relational matrices indebted to transnationalism and globalization (Appadurai 1991; also Satzewich et al. 2006).

In undertaking such work, an exploration of the preliminary choice to privilege the expression and experience of difference remains foundational. With this comes an acknowledgement that music can enunciate this position strategically and effectively. Furthermore, a meaningful consideration of the musical past (whether real or imagined) should be implicated as a potentially valuable context for elaborating ongoing reformulations of expressive culture as an essential component of the social and political realities of the present.

\section{REFERENCES}

Adams, Michael. 2007. Unlikely Utopia: The Surprising Triumph of Canadian Pluralism. Toronto: Viking Canada.

Appadurai, Arjun. 1991. "Global Ethnoscapes: Notes and Queries for a Transnational Anthropology." In Recapturing Anthropology: Working in the 
Present, edited by Richard G. Fox, 191-210. Santa Fe, New Mexico: School of American Research Press.

Bhabha, Homi K. 1998. "Culture's in between," in Multicultural States: Thinking Difference and Identity, ed. David Bennett, 29-36. New York: Routledge.

Booth, Gregory. 2000. "Religion, Gossip, Narrative Conventions and the Construction of Meaning in Hindi Film Songs." Popular Music 19(2): $125-45$.

Braid, Donald. 1996. "Personal Narrative and Experiential Meaning." The Journal of American Folklore 109(431): 5-30.

Breyley, Gay. 2007. "Diasporic Transpositions: Indigenous and Jewish Performances of Mourning in $20^{\text {th }}$-Century Australia." Ethnomusicology Forum 16(1): 95-126.

Butler, Gary R. 1992. "Indexicality, Authority, and Communication in Traditional Narrative Discourse." The Journal of American Folklore 105(415):34-56.

Butler, Judith. 1990/2006. Gender Trouble. New York: Routledge.

Clifford, James. 1997. "Diasporas." In Routes: Travel and Translation in the Late Twentieth Century, 244-77. Cambridge, Massachusetts: Harvard University Press.

Cooley, Timothy. 2005. Making Music in the Polish Tatras. Bloomington: Indiana University Press.

Cooley, Timothy and R. Spottswood. 1997a. "Fire in the Mountains: Polish Mountain Fiddle Music-Vol. 1-The Karol Stoch Band." Compact disc recording with notes. Newton, J.J.: Yazoo, a division of Shanachie Entertainment Corp.

- 1997b. "Fire in the Mountains: Polish Mountain Fiddle MusicVol. 2-The Great Highland Bands." Compact disc recording with notes. Newton, J.J.: Yazoo, a division of Shanachie Entertainment Corp.

Ćwiżewicz, Krzysztof. 2001. "Musical Rites of Entertainment among Górale of the Polish Tatra Mountains." Ph.D. dissertation, University of London, Goldsmiths' College.

Ćwiżewicz, Krzysztof, and Barbara Ćwiżewicz. 1995. "Music of the Tatra Mountains: The Trebunia Family Band." Compact disc recording with notes. Monmouth: Nimbus Records.

Diamond, Beverley. 1994. "Introduction: Issues of Hegemony and Identity in Canadian Music." In Canadian Music: Issues of Hegemony and Identity, ed. Beverley Diamond and Robert Witmer, 1-21. Toronto: Canadian Scholar's Press.

- 2000. "What's the Difference? Reflections on Discourses of Morality, Modernism, and Mosaics in the Study of Music in Canada." Canadian University Music Review 21(1): 54-75.

- 2001."Identity, Diversity, and Interaction." In the Garland Encyclopedia of World Music, Vol. 3, The United States and Canada, ed. Ellen Koskoff, 1056-1065. New York: Garland.

Dimitriadis, Greg. 1996. "Hip Hop: From Live Performance to Mediated Narrative." Popular Music 15(2): 179-94. 
Fairley, Jan. 1989. “Analysing Performance: Narrative and Ideology in Concerts by ¡Karazu!" Popular Music 8(1): 1-30.

Feld, Steven. 1984. "Communication, Music, and Speech about Music." Yearbook for Traditional Music 16: 1-18.

Hall, Stuart. 1990/1996. "Cultural Identity and Diaspora." In Contemporary Postcolonial Theory: A Reader, ed. Padmini Mongia, 110-121. New York: St. Martin's Press.

Karpiel Bułecka, Jan, and Barbara Pikulska-Krajewska. 2000. Spiewnik góralski dla ceprów. [Górale Songbook for Foreigners]. Wrocław: Wydawnictwo ABsonic.

Keil, Charles. 1994. "Participatory Discrepancies and the Power of Music." In Music Grooves: Essays and Dialogues,ed. Charles Keil and Steven Feld, 96-108. Chicago: University of Chicago Press.

Kirshenblatt-Gimblett, Barbara. 1995. "Theorizing Heritage." Ethnomusicology 39(3): 367-80.

Lord, Albert B. 1960/1976. The Singer of Tales. New York: Atheneum.

Manouelian, Edward. 2000. "Invented Traditions: Primitivist Narrative and Design in the Polish Fin de Siècle." Slavic Review 59(2): 391-405.

Mierczyński, Stanisław. 1930/1973. Muzyka Podhala. Warsaw: Polskie Wydawnictwo Muzyczne.

Motyka, Władysław, ed. 2004. Śpiewnik górali polskich. Milówka: Beskidzkie Towarzystwo Oświatowe.

Nattiez, Jean-Jacques. 1990. "Can One Speak of Narrativity in Music?" Journal of the Royal Musical Association 115(2): 240-57.

New Grove Dictionary of Music and Musicians. S.v. "Poland II: Folk Music." (By Jan Stęszewski.) London: Macmillan.

Pine, Frances. 1992. "Uneven Burdens: Women in Rural Poland." In Women in the Face of Change: The Soviet Union, Eastern Europe and China, ed. Shirin Rai, Hilary Pilkington and Annie Phizacklea, 57-75. New York: Routledge.

- 1996. "Naming the House and Naming the Land: Kinship and Social Groups in Highland Poland." The Journal of the Royal Anthropological Institute 2(3): 443-59.

Przerwa-Tetmajer, Kazimierz.1957.NaSkalnem Podhalu.Krakow:Wydawnictwo Literackie.

Ramnarine, Tina. 2007. "Musical Performance in the Diaspora: Introduction." Ethnomusicology Forum 16(1): 1-18.

Rice, Timothy. 1994. May It Fill Your Soul: Experiencing Bulgarian Music. Chicago: University of Chicago Press.

- 2001."Reflections on Music and Meaning: Metaphor, Signification, and Control in the Bulgarian Case." British Journal of Ethnomusicology 10(1):19-38.

Sadownik, Jan, ed. 1957/1971. Pieśni Podhala: Antologia. Krakow: Polskie Wydawnictwo Muzyczne.

Safran, William. 1999. “Comparing Diasporas: A Review Essay." Diaspora 8(3): 255-91. 
Satzewich, Vic and Lloyd Wong, eds. 2006. Transnational Identities and Practices in Canada. Vancouver: UBC Press.

Schieffelin, Edward L. 1985. "Performance and the cultural construction of reality." American Ethnologist 12(4): 707-724.

Slobin, Mark. 1993/2000. Subcultural Sounds: Micromusics of the West. $2^{\text {nd }}$ ed. Hanover: Wesleyan University Press.

—. 2003. "The Destins of 'Diaspora' in Ethnomusicology." In The Cultural Study of Music: A Critical Introduction, edited by Martin Clayton, Trevor Herbert, Richard Middleton, 284-96. New York: Routledge.

Stock, Jonathan P. "Musical Narrative, Ideology, and the Life of Abing." Ethnomusicology 40(1): 49-73.

Sugarman, Jane C. 1997. Engendering Song: Singing and Subjectivity at Prespa Albanian Weddings. Chicago: University of Chicago Press.

Tokita, Alison McQueen. 1996. "Mode and Scale, Modulation and Tuning in Japanese Shamisen Music: The Case of Kiyomoto Narrative." Ethnomusicology 40(1): 1-33.

Weintraub, Andrew N. 1994. "Tune, Text, and the Function of Lagu in Pantun Sunda: A Sundanese Oral Narrative Tradition." Asian Music 26(1): 175-211.

Wnuk, Wlodzimierz. 1985. Górale za Wielka Wodą. Warsaw: Ludowa Społdzielnia Wydawnicza.

Wrazen, Louise. 1988. "The Góralski of the Polish Highlanders: Old World Musical Tradition from a New World Perspective." Ph.D. dissertation, University of Toronto.

—. 1991. "Traditional Music Performance among Górale in Canada." Ethnomusicology 35/2: 173-93.

- 2004. "Men and Women Dancing in the Remembered Past of Podhale Poland." The Anthropology of East Europe Review 22(1): 145-54.

- 2005. "Diasporic Experiences: Mediating Time, Memory and Identity in Górale Performance." The Canadian Journal for Traditional Music 32:43-51

- 2007. "Relocating the Tatras: Place and Music in Górale Identity and Imagination." Ethnomusicology 51(2):185-204.

- Forthcoming. "Beyond the Polish Tatras: Performing Pride, Identity, or Difference," Bulgarian Musicology (special issue devoted to proceedings of the ICTM Study Group on Music and Minorities).

Zhang, Wei-hua. 1992. "Music in Ming Daily Life, as Portrayed in the Narrative 'Jin Ping Mei.' Asian Music 23(2): 105-34.

Znaniecki, Florian and William I.Thomas. 1996. The Polish Peasant in Europe and America: a Classic Work in Immigration History. Abridged and edited by Eli Zaretsky. Urbana: University of Illinois Press.

\section{ABSTRACT}

The traditional singing of Gorale from the Tatra mountain region of Podhale favours a single phrase of melody and two lines of text. The narrative significance of this sing- 
ing is traced from homeland to diaspora: collectively, these songs constitute a regional narrative that in Poland provided the framework for personal expressions constructed spontaneously in performance and embedded in social discourse; in Canada, the individual story is subsumed in favour of a collective narrative that locates a meaningful space between these two worlds. Ultimately, the centrality of music in the experience and deliberate expression of difference within an evolving multicultural, transnational, globalized reality is reinforced.

\section{RESUME}

Le chant traditionnel des Górale de la région montagneuse des Tatra en Podhale se caractérise par une simple phrase mélodique et deux lignes de texte. Limportance narrative de ce chant est présentée, de ses racines à la diaspora : collectivement, ces chants constituent un récit régional en Pologne qui offre le cadre d'expressions personnelles construites spontanément dans laction et intégrées au discours social; au Canada, le récit individuel est subsumé au profit d'une narration collective qui situe un espace significatif entre ces deux mondes. En dernière analyse, la centralité de la musique dans l'expérience et l'expression délibérée de différence est renforcée au sein d'une réalité multiculturelle, transnationale et globalisée. 